\title{
Memanfaatkan Potensi dan Keindahan Bangunan Kolonial melalui Alih Fungsi Bangunan Studi Kasus: Heritage the Factory Outlet di Jl Riau Bandung
}

\author{
Nurtati Soewarno \\ Institut Teknologi Nasional, Bandung, Indonesia \\ Email: nurtati@itenas.ac.id
}

Received 30 June 2020 | Revised 10 October 2020| Accepted 14 October 2020

\begin{abstract}
ABSTRAK
Bangunan peninggalan kolonial merupakan warisan budaya yang saat ini banyak dialih fungsikan terutama untuk fungsi komersial. Bangunan ini mempunyai gaya arsitektur yang unik dan beradaptasi terhadap iklim tropis dengan penerapan bukaan lebar, plafond tinggi dan atap bersudut tajam. Penelitian ini bertujuan untuk mengeksplorasi bagaimana memanfaatkan potensi bangunan peninggalan kolonial. Dengan melakukan observasi diperoleh data bahwa keindahan gaya arsitektur menjadi daya tarik pengunjung dan dengan tata letak furniture yang tepat akan diperoleh kenyamanan termal dan pencahayaan alami yang optimal. Heritage the Factory Outlet dipilih sebagai kasus studi karena alih fungsi terbilang sukses, tidak menghilangkan keaslian gaya arsitekturnya bahkan menjadikannya daya tarik tersendiri. Bangunan tambahan di bangun tidak lebih menonjol dari bangunan utama sehingga keberhasilan alih fungsi ini diharapkan dapat diterapkan pada bangunan cagar budaya lainnya. Diperlukan dukungan Pemerintah Daerah dalam pengawasan pelaksanaan perubahan agar tidak melanggar aturan konservasi dan menindak tegas segala bentuk pelanggaran yang dapat merusak bangunan sebagai warisan budaya.
\end{abstract}

Kata kunci: bangunan peninggalan kolonial, alih fungsi, adaptasi gaya arsitektur, bangunan cagar budaya, adaptive reuse

\begin{abstract}
Colonial heritage buildings are cultural heritages that nowadays many of them are undergoing functional shift, mainly into commercial function. These buildings have an architectural style that adapt to tropical climate by applying wide openings, high ceilings with sharp angeled roof. This research goal is to explore how to benefit the potential of colonial heritage buildings. Observation results showed that beauty of the architectural style is the attraction for visitors together with the right furniture layout, thermal comfort and optimal natural lighting. "Heritage" Factory Outlet was selected as a case study because of the function shift was successful, does not eliminate the beauty of the architectural style and in fact it becomes its unique attraction. The additional building does not become more prominent of the main building so that the succes of function shift is expected to be applied to other cultural heritage building. Local Government support is required in monitoring the implementation of changes that do not violate the rules of conservation and take firm action against any violation that may damage the building as a cultural heritage.
\end{abstract}

Keywords: Colonial heritage building, building function shift, architecture style addaptation, cultural heritage building, adaptive reuse 


\section{PENDAHULUAN}

Kota Bandung terletak $700 \mathrm{~m}$ di atas permukaan laut dengan temperatur $27^{0}$ di siang hari dan $17^{0}$ di malam hari, kondisi ini oleh pemerintah Kolonial Belanda dianggap sangat nyaman dan sehat untuk kehidupan pada saat itu (Referensi terkait data temperatur yang ditampilkan). Hal ini menjadi faktor pendorong perluasan kota dan menjadikan Bandung sebagai kota Kolonial (Koloniale stad) yang sejalan dengan rencana pemerintah memindahkan ibu kota Hindia Belanda dari Batavia (Jakarta saat ini) ke Bandung. [1]

Dari catatan sejarah perkembangan kota Bandung menunjukan data pada tahun 1936, 52\% dari wilayah pemukiman di kota Bandung dihuni oleh bangsa Eropa yang berlokasi di 'Jubileumpark', yaitu kawasan hunian yang membentang dari Taman Lalu Lintas sampai ke Gedung Sate[2]. Bangunan-bangunan di kawasan ini mempunyai bentuk dan gaya arsitektur kolonial yang merupakan perpaduan gaya arsitektur barat dan timur [3]. Sebagian besar bangunan-bangunan tersebut masih bertahan hingga saat ini, seperti pada hunian di sepanjang jalan R.E Martadinata (dahulu jl Riau).

Lokasi yang strategis, menjadi salah satu potensi yang menyebabkan sebagian besar bangunan telah beralih fungsi, salah satunya adalah bangunan eks villa yang terletak di simpang jalan R.E Martadinata - jalan Banda. Bangunan berwarna putih ini telah beberapa kali beralih fungsi dan sejak tahun 2000 digunakan sebagai factory outlet [4]. Ciri khas dari bangunan ini adalah deretan tiang Yunani Doric berwarna putih dan saat ini menjadi satu-satunya bangunan The Empire Style yang masih tersisa di kota Bandung.

Makalah ini bertujuan untuk mengeksplorasi bagaimana pemanfaatan ruang-ruang dalam pada eks bangunan hunian kolonial. Apakah alih fungsi mempertimbangkan potensi yang dimiliki oleh bangunan, seperti ketinggian plafond, bukaan pintu dan jendela yang lebar dan keindahan gaya arsitektur? Bagaimana gaya arsitektur yang diterapkan pada bangunan tambahan? Alih fungsi ini dinilai berhasil karena tidak menghilangkan keaslian bangunan cagar budaya, yaitu deretan tiang Yunani Doric dan atap kubah pada pintu masuk utama.

Selain itu makalah ini akan memaparkan kondisi awal bangunan sejak beralih kepemilikan dan bagaimana proses renovasi berjalan. Tidak hanya bentuk dan gaya arsitektur saja yang dipertahankan tetapi material yang digunakan dipertahankan pula, seperti lantai, plafond dan kusen-kusen pintu jendela. Demikian pula pada pergantian material bangunan yang sudah lapuk, dipilih bahan yang sifatnya netral dan selaras dengan material asli, seperti penggunaan plafond gypsum putih polos sebagai pengganti plafond bermotif. Kelebihan lain dari alih fungsi pada bangunan ini renovasi yang dilakukan mengikuti aturan konservasi untuk sebuah bangunan cagar budaya kelas A dan pada pelaksanaannya mendapat pengawasan langsung oleh team cagar budaya Bandung.

Bentuk adaptasi lain terhadap fungsi baru adalah tambahan ruang atau bangunan. Untuk menjaga keselarasan dengan bangunan cagar budaya, maka gaya arsitektur bangunan tambahan sebaiknya konteks terhadap gaya bangunan konservasi agar dapat bersanding dengan harmonis. Menurut Brolin [5], kontekstualisme adalah kemungkinan perluasan bangunan dan keinginan mengaitkan bangunan baru dengan lingkungan sekitarnya. Oleh karenanya disain bangunan baru harus fit dan merespon lingkungannya dan atau menjadi perantara dengan lingkungannya. Hal senada juga diutarakan Anthony C. Antoniades [6], bahwa kontekstual merupakan suatu hubungan antara arsitektur dan site-nya, berkaitan dengan lingkungan sekitarnya dengan memperhatikan kondisi bangunan sekitar, dimana masyarakat, budaya, area, dan materialnya berasal dari tempat arsitektur tersebut akan dibangun. Oleh karenanya gaya bangunan tambahan pada sisi kiri dan belakang dibuat sederhana.

Heritage the Factory Outlet menjadi pelopor perubahan bangunan di sepanjang J1 R.E Martadinata dan keberhasilan alih fungsi pada bangunan ini diharapkan dapat ditiru oleh bangunan cagar budaya lainnya di sepanjang jalan ini maupun dilokasi lain di kota Bandung dan kota lainnya di Indonesia. Saat ini hampir seluruh bangunan hunian di sepanjang jalan R.E Martadinata telah beralih fungsi menjadi 
bangunan komersial yang didominasi oleh distro dan rumah makan sehingga jalan ini menjadi salah satu tujuan wisatawan datang ke kota Bandung pada akhir pekan maupun saat hari libur.

\section{METODOLOGI}

Proses keberlanjutan arsitektur meliputi keseluruhan siklus masa suatu bangunan, mulai dari proses pembangunan, pemanfaatan, pelestarian dan pembongkaran bangunan [7]. Dalam hal pelestarian saat ini banyak bangunan konservasi dilestarikan dengan metoda adaptive reuse. Joachim [8], menyatakan "Adaptive reuse is defined as the aesthetic process that adapts buildings for new uses while retaining their historic features. Using an adaptive reuse model can prolong a building's life, from cradle-tograve, by retaining all or most of the building system, including the structure, the shell and even the interior materials". Hal senada juga diutarakan oleh Brebbia dkk [9] bahwa adaptive reuse adalah proses menggunakan kembali situs atau bangunan tua untuk tujuan yang berbeda dari tujuan awal dan merupakan upaya konservasi.

Data mengenai sejarah pendirian dan kepemilikan bangunan diperoleh melalui berbagai literatur sehingga gambaran mengenai masa lalu bangunan dan kawasan dapat terbayangkan. Demikian pula data lapangan sebelum dan pada saat renovasi berlangsung diperoleh melalui beberapa literatur, foto dan melakukan wawancara dengan Bapak Drs Dibyo Hartono, M.Sn selaku ketua Bandung Heritage pada saat itu. Sedangkan untuk mengetahui kondisi terkini dilakukan survey ke objek studi melihat perkembangan penggunaan ruangan-ruangan pada bangunan asli dan bangunan tambahan. Digunakan metoda kualitatif untuk menganalisis data hasil baik survey literatur, wawancara dan survey lapangan yang kemudian dikomparasi antara teori dan kondisi di lapangan.

\section{HASIL DAN PEMBAHASAN}

\subsection{Tipologi Bangunan Kolonial}

Arsitektur kolonial merupakan perpaduan antara timur dan barat yang hadir melalui karya-karya arsitek Belanda yang diperuntukan bagi bangsa Belanda di Indonesia pada masa sebelum kemerdekaan [10]. Menurut Hadinoto [11] gaya arsitektur bangunan kolonial di Indonesia dibagi menjadi 4 tahap perkembangan berdasarkan situasi politik, yaitu (gambar 1):

a. Abad ke 16 sampai dengan tahun 1800 an, pada saat itu Nederland Indische masih di bawah kekuasaan perusahaan dagang VOC (Vereenig de Oost Indische Compagnie) sehingga tidak ada kejelasan gaya arsitektur pada bangunan kolonial.

b. Tahun 1800 sampai tahun 1902, setelah mengambil alih VOC kondisi ekonomi negeri Belanda meningkat sehingga bangunan-bangunannya didirikan megah dengan menerapakan gaya arsitektur Neo-klasik. Gaya tersebut disebut The Empire Style, yaitu gaya arsitektur kolonial yang menyesuaikan dengan kondisi iklim, lingkungan dan menggunakan material lokal.

c. Tahun 1902-1920 an, pada saat itu kaum liberal di negeri Belanda mendesak 'politik etis' untuk diterapkan di tanah jajahan. Akibatnya The Empire Style terdesak dan berganti dengan gaya arsitektur modern yang berorientasi terhadap gaya arsitektur di negeri Belanda saat itu.

d. Tahun 1920-1940 an, pada masa ini muncul gerakan pembaruan dalam arsitektur, baik nasional maupun internasional di Belanda yang berpengaruh terhadap gaya arsitektur kolonial di Indonesia. Pada masa ini muncul arsitek Belanda yang memandang perlu untuk memberi ciri khas arsitektur Hindia Belanda dengan arsitektur tradisional Indonesia. Terdapat dua aliran gaya, yang pertama adalah gaya arsitektur Indisch dengan sumber arsitektur tradisional dan yang kedua adalah gaya arsitektur modern dengan penyesuaian terhadap iklim, teknologi dan material lokal. 


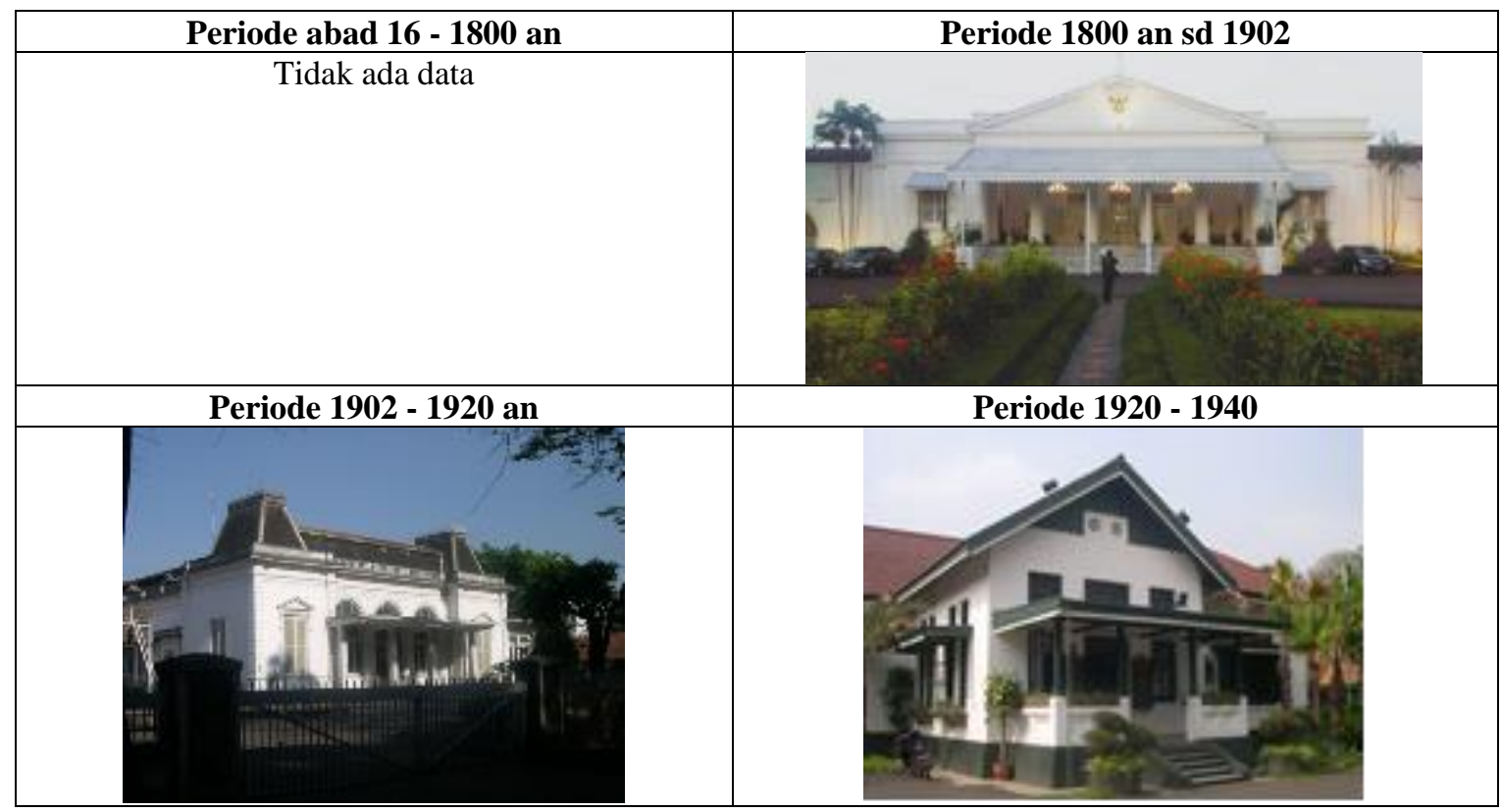

Gambar 1. Tipologi Bangunan Kolonial

\subsection{Bangunan Cagar Budaya}

Peraturan Menteri Pekerjaan Umum dan Perumahan Rakyat Republik Indonesia Nomor: 01/PRT/M/2015 tentang Bangunan Gedung Cagar Budaya Yang Dilestarikan menyatakan bahwa bangunan gedung cagar budaya adalah bangunan gedung yang sudah ditetapkan statusnya sebagai bangunan cagar budaya sesuai dengan ketentuan peraturan perundang-undangan tentang cagar budaya.

Adapun kriteria bangunan cagar budaya dalam pasal 5 Undang-undang nomor 11 tahun 2010 adalah:

a. berusia 50 (lima puluh) tahun atau lebih

b. mewakili masa gaya paling singkat berusia 50 tahun

c. memiliki arti khusus bagi sejarah, ilmu pengetahuan, pendidikan, agama dan/atau kebudayaan dan

d. memiliki nilai budaya bagi penguatan kepribadian bangsa.

Sedangkan menurut Peraturan Daerah Kota Bandung No.19 tahun 2009 tentang Pengelolaan Kawasan dan Bangunan Cagar Budaya, ada 5 kriteria dalam penentuan kawasan dan bangunan cagar budaya, yaitu:
a. mempunyai nilai sejarah
b. mempunyai nilai arsitektur
c. mempunyai nilai ilmu pengetahuan
d. mempunyai nilai sosial budaya
e. umur bangunan.

Kriteria di atas menentukan klasifikasi bangunan cagar budaya (A-utama, B-madya atau C-pratama) dan akan menentukan tindakan pada saat dilakukan pemugaran bangunan. Semakin tinggi golongannya, maka aturan pemugaran bangunan akan semakin ketat.

\section{HERITAGE THE FACTORY OUTLET}

\subsection{Latar Belakang Sejarah}

Lokasi bangunan berada di jalan R.E Martadinata (dahulu jl. Riau) yang pada waktu itu dianggap sebagai kawasan yang masih tenang, bersih, sehat, dengan lingkungan alam indah dan nyaman di bagian utara kota Bandung. Rumah ini diperkirakan merupakan villa milik seorang pengusaha atau seorang pimpinan permerintahan berkebangsaan Belanda yang dibangun pada saat kota Bandung telah memperoleh status mandiri sebagai Gemeente, (1 April 1906) [1]. 
Bangunan ini merupakan bangunan pojok yang paling unik, yang didisain dengan acuan pada sejarah tradisi arsitektur Barat masa lalu. Perkiraan waktu pembangunan pada awal abad ke 19 ini didukung oleh data bangunan yang menggunakan bahan langit-langit dekoratif dari bahan plat besi tipis pres (gestampt dun plaatijzeren) yang banyak diproduksi di negeri Belanda pada dekade pertama abad 20 (en dateren uit het eerste decenium van de 20ste eeeuw) [12].

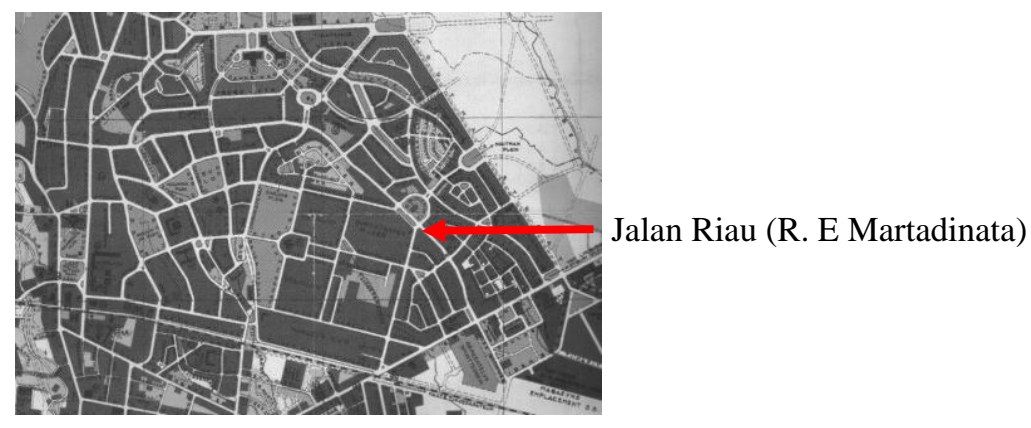

Gambar 2. Lokasi jl. R.E Martadinata (Riau), Kelurahan Cihapit, Kecamatan Bandung Wetan-Bandung

Bangunan ini tidak didisain oleh seorang arsitek karena pada periode awal abad 20 masih belum ada arsitek profesional. Bangunan umumnya direncanakan oleh ahli teknik BOW (Bugerlijke Openbare Werken) atau langsung direncanakan dan dilaksanaka oleh kontraktor. Dalam menelaah bangunan kolonial tidak lepas dari gaya arsitektur yang dibawa oleh bangsa Belanda pada saat itu. Ada tiga ciri yang harus diperhatikan untuk dapat memahami struktur ruang lingkup sosial kota kolonial, yaitu: budaya, teknologi dan struktur kekuasaan kolonial [13]. Demikian dengan rumah ini, pada saat pembangunannya banyak memperoleh intervensi disain dari ibu-ibu rumah tangga teman pemilik bangunan yang banyak mempelajari tentang pembangunan rumah dari buku-buku Belanda, salah satunya adalah 'Ons huis in Indie' yang berisi tentang rumah tradisional kolonial karya Mevrouw Catenius van der Meijden yang cukup terkenal pada saat itu [12].

Bangunan ini telah melalui tahap revitalisasi (mengacu pada sejarah arsitektur neoklasik) yang cukup baik, karena penampilan fisik luar bangunan lama tetap dipertahankan dan dirawat dengan baik sesuai dengan Peraturan Daerah Kota Bandung no. 19 tahun 2009 yang mengatur bangunan-bangunan yang termasuk kriteria bangunan yang dikonservasikan. Beberapa bangunan di jalan R.E Martadinata merupakan bangunan-bangunan cagar budaya dengan berbagai klasifikasi. [14] Selain itu jalan Riau juga merupakan salah satu kawasan perumahan mewah tertua di kota Bandung, oleh karenanya diperlukan perlindungan dari Pemerintah Daerah dan masyarakat [2].

Bangunan ini telah beralih kepemilikan dari kepemilikan pribadi kepada BUMN milik negara, yaitu P.T Kimia Farma. Demikian pula dengan fungsinya telah beberapa kali beralih fungsi. Sejak beralih kepemilikan bangunan ini disewa untuk tempat kursus bahasa Inggris lalu pernah pula dipakai untuk sekolah khusus untuk para manager Bank dan sejak tahun 2000 hingga saat ini menjadi factory outlet dengan nama 'Heritage the Factory Outlet' [4].

\subsection{Kondisi Awal sebagai Rumah Tinggal}

Kondisi awal yang dimaksud dalam makalah ini adalah kondisi pada saat bangunan diserahkan oleh pemilik (P.T Kimia Farma) kepada team cagar budaya untuk direnovasi untuk kemudian digunakan menjadi factory outlet. Fungsi sebelumnya adalah tempat kursus yang tidak memerlukan ruang tambahan sehingga secara fisik bangunan tidak berubah hanya ada penambahan 3 pilar di bagian muka yang dibuat meniru pilar utama (gambar 3). Bangunan memerlukan perawatan dan perbaikan yang serius dan karena bangunan termasuk bangunan konservasi golongan A, maka pemilik menyerahkan kepada tim Bandung Heritage dipimpin oleh Bapak Drs Dibyo Hartono, M.Sn untuk melakukan renovasi dan mengembalikan bangunan ke bentuk semula. 

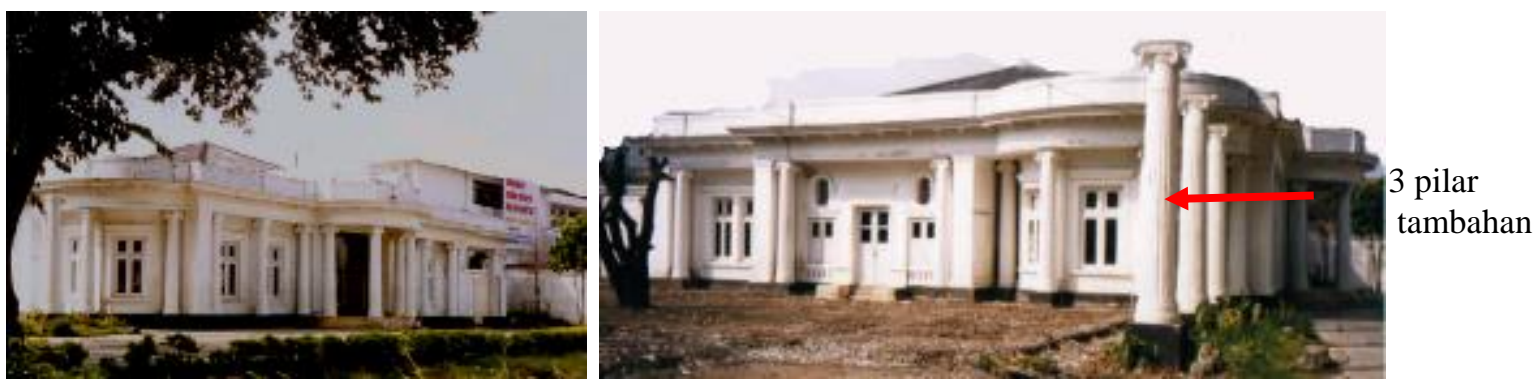

Gambar 3. Tampak dari jl. R.E Martadinata dan jl. Banda

Tingginya curah hujan menjadikan kerusakan terutama terjadi pada bagian atap sehingga $50 \%$ dari konstruksi utama diganti dengan tidak merubah bentuk atap terutama atap pada main entrance yang merupakan bagian yang paling penting dan menarik dari bangunan ini (gambar 4). Atap yang digunakan pada bangunan ini merupakan perpaduan antara atap perisai dan atap dak. Hal ini mencerminkan adanya perpaduan antara 2 bangsa yang saling beradaptasi yang dinamakan arsiektur kolonial [15]

Bagian yang tak kalah penting dan menarik adalah kolom doric bergaya Yunani yang berderet simetris pada sisi kiri dan kanan dari main entrance. Façade bangunan merupakan elemen arsitektur yang penting yang dapat menggambarkan kondisi masa lampau baik budaya maupun kondisi sosial dan ekonomi [16].

Penggunaan material yang baik dan pelaksanaan yang apik menjadikan bagian lain dari bangunan seperti kolom, kusen jendela dan pintu serta lantai tidak memerlukan penggantian hanya penambalan dan pengecatan ulang. Berbeda halnya dengan plafond yang terkena dampak dari rusaknya bagian atap sehingga memerlukan penanganan yang serius. Sulitnya menemukan material asli menjadikan beberapa bagian plafond diganti dengan tripleks dan gypsum tanpa motif. Demikian pula dengan bahan lantai bermotif yang juga sulit dicari penggantinya (gambar 4).

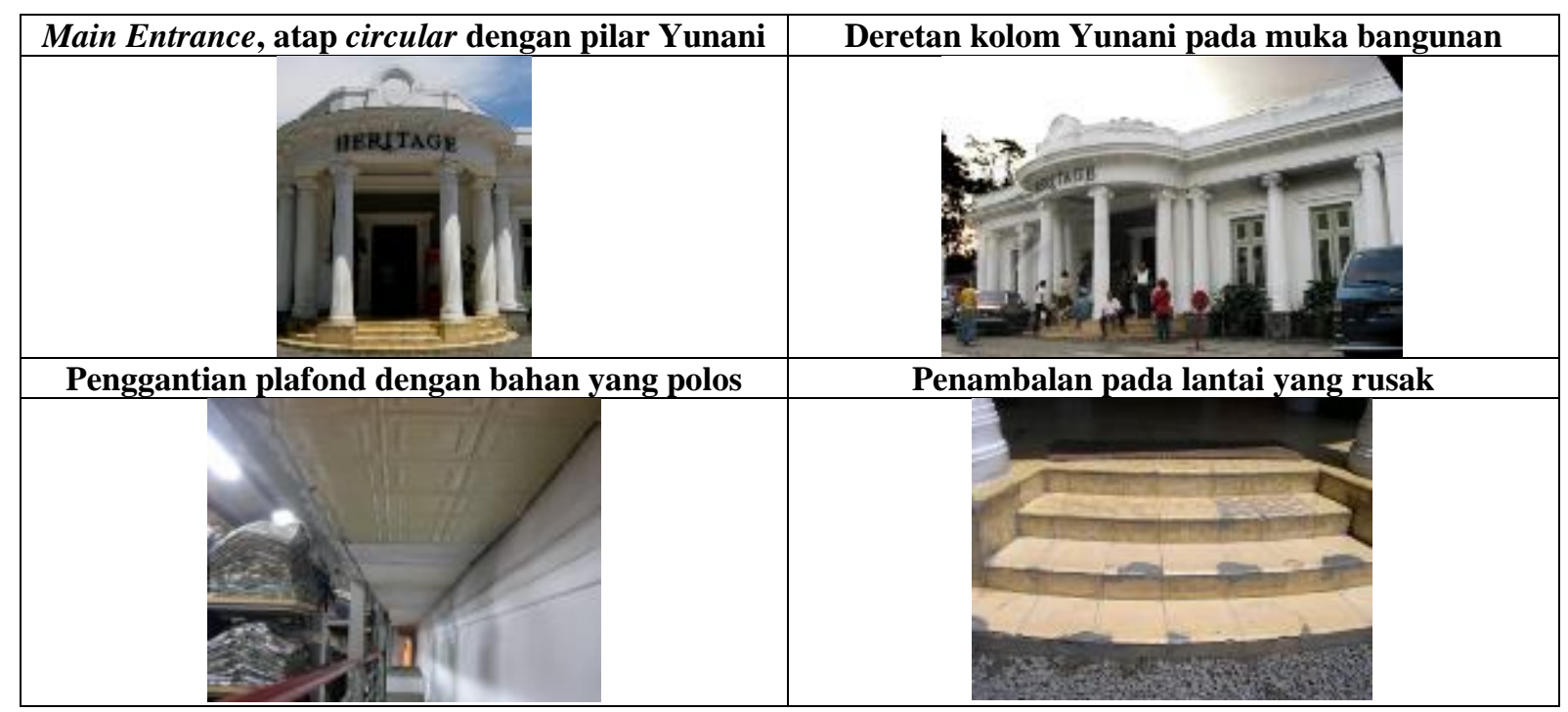

Gambar 4: Main Entrance, deretan kolom Yunani dan penggantian bahan plafond dan lantai

\subsection{Alih fungsi menjadi Factory Outlet}

Sejalan dengan berlalunya waktu banyak terjadi perubahan fungsi pada bangunan-bangunan lama, dimulai dari jl Cihampelas, jl Dago yang kemudian merembet ke jalan-jalan utama terutama di utara kota Bandung. Kawasan yang semula diperuntukan sebagai kawasan hunian menjadi kawasan non hunian yang memicu peralihan fungsi bangunan hunian menjadi non hunian. Demikian pula yang terjadi 
di jl R.E Martadinata, hal ini merujuk pada Rencana Detail Tata Ruang (RDTR) Kota Bandung tahun 2015, yang menyebutkan bahwa koridor Jalan L.L.R.E. Martadinata direncanakan sebagai kawasan perdagangan dan jasa linier, wisata, pelayanan umum serta pertahanan dan keamanan [14].

Heritage the Factory Outlet menjadi pelopor perubahan fungsi bangunan di jl R.E Martadinata, karena bangunan ini sejak berganti kepemilikan telah beberapa kali difungsikan untuk kegiatan non hunian dan baru pada tanggal 2 Desember 2000 diresmikan sebagai Factory Outlet.

Tingginya kebutuhan akan ruang pamer menjadikan semua ruangan yang ada dipergunakan seluruhnya sebagai show room (gambar 5). Beragamnya fashion yang dijual tidak dapat dipenuhi oleh seluruh ruangan yang tersedia sehingga untuk memenuhi kebutuhan akan sebuah tempat belanja yang lengkap maka diperlukan tambahan ruang. Hal ini memungkinkan karena masih tersisa cukup lahan di sekeliling bangunan yang semula berupa taman, sesuai dengan konsep bangunan villa.

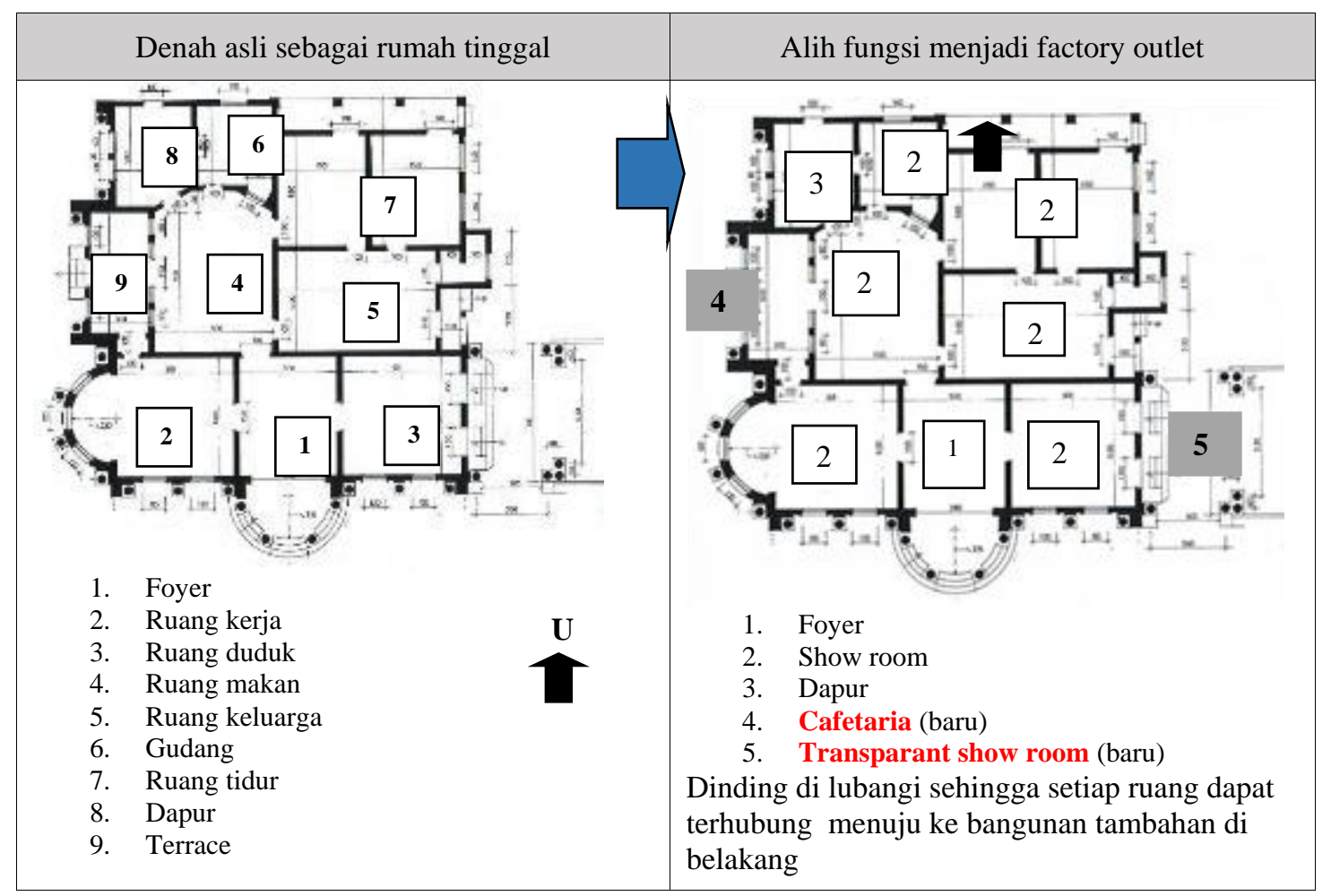

Gambar 5: Alih fungsi ruang-ruang dalam bangunan

Tambahan ruang dengan memanfaatkan sisa lahan yang masih tersedia di seputar bangunan dengan mengikuti ketentuan yang ditetapkan oleh team cagar budaya Bandung, yaitu: tidak dibenarkan membangun bangunan permanen di depan bangunan lama. Oleh karenanya ruang dan bangunan tambahan dibuat disekitarnya, berupa: (Gambar 6)

a. kafetaria semi permanen transparan di sisi kiri bangunan, menghadap ke jalan Banda

b. bangunan baru di bagian belakang didirikan dengan gaya bangunan kontras, baik struktur maupun bahan bangunan. Konsep kontras diterapkan untuk mendukung eksistensi bangunan utama dan menjadi background dari bangunan utama.

c. penutupan bagian samping kanan dengan dinding transparan (kaca) untuk perluasan toko. 


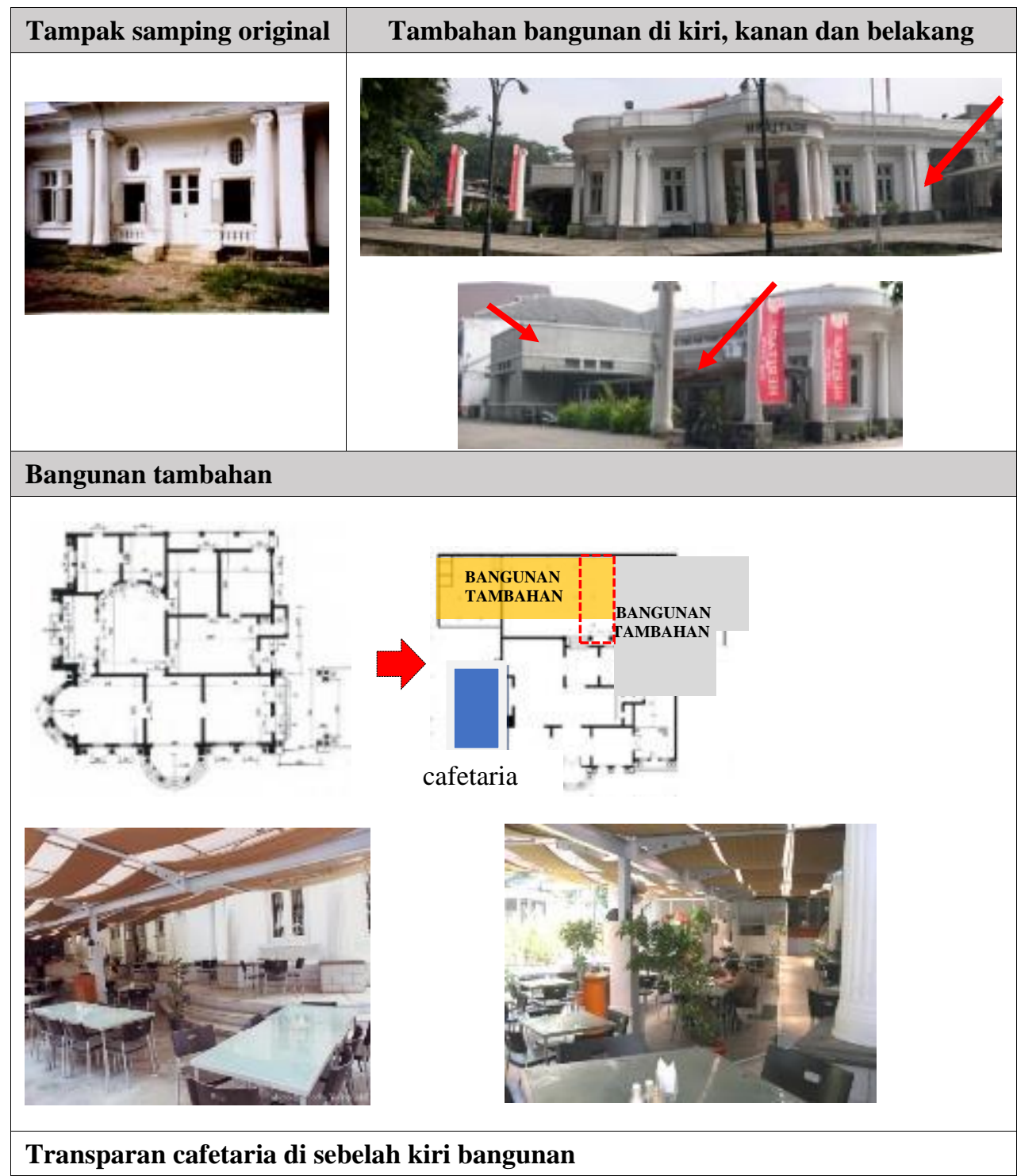

Gambar 6: Bangunan tambahan di bagian belakang dan samping kiri

\subsection{Adaptasi Gaya Arsitektur}

Dari hasil pengukuran diperoleh data luas lahan $47 \times 63$ m yaitu $2.983 \mathrm{~m}^{2}$ sedangkan luas bangunan adalah $380 \mathrm{~m} 2$ sehingga masih memungkinkan didirikan bangunan tambahan di sekeliling bangunan (gambar 4). Merujuk kepada peraturan konservasi yang ditetapkan oleh Bandung Heritage, maka bangunan tambahan hanya memungkinkan didirikan di bagian belakang saja. Ketentuan lain yang harus diikuti adalah penggunaan gaya arsitektur bangunan tambahan harus kontras dengan gaya arsitektur bangunan utama sebagai bangunan konservasi tetapi tidak boleh lebih menonjol dari bangunan utama. Diperoleh pula data ketinggian bangunan utama yang mencapai 4,7 $\mathrm{m}$ menjadi potensi yang memungkinkan bagi bangunan tambahan dibangun 2 lantai sehingga dapat memenuhi tuntutan kebutuhan ruang yang cukup tinggi karena beragamnya fashion yang dijual.

Untuk kemudahan dan kecepatan pembangunan, maka konstruksi baja dipilih selain sebagai struktur utama bangunan tambahan. Hal ini dengan pertimbangan material mudah didapat, pengerjaan dapat dilakukan di luar site (pre-fabrikasi) sehingga mempercepat pengerjaan (Gambar 7). 
Memanfaatkan Potensi dan Keindahan Bangunan Kolonial melalui Alih Fungsi Bangunan

Studi Kasus: Heritage the Factory Outlet

di Jl Riau Bandung

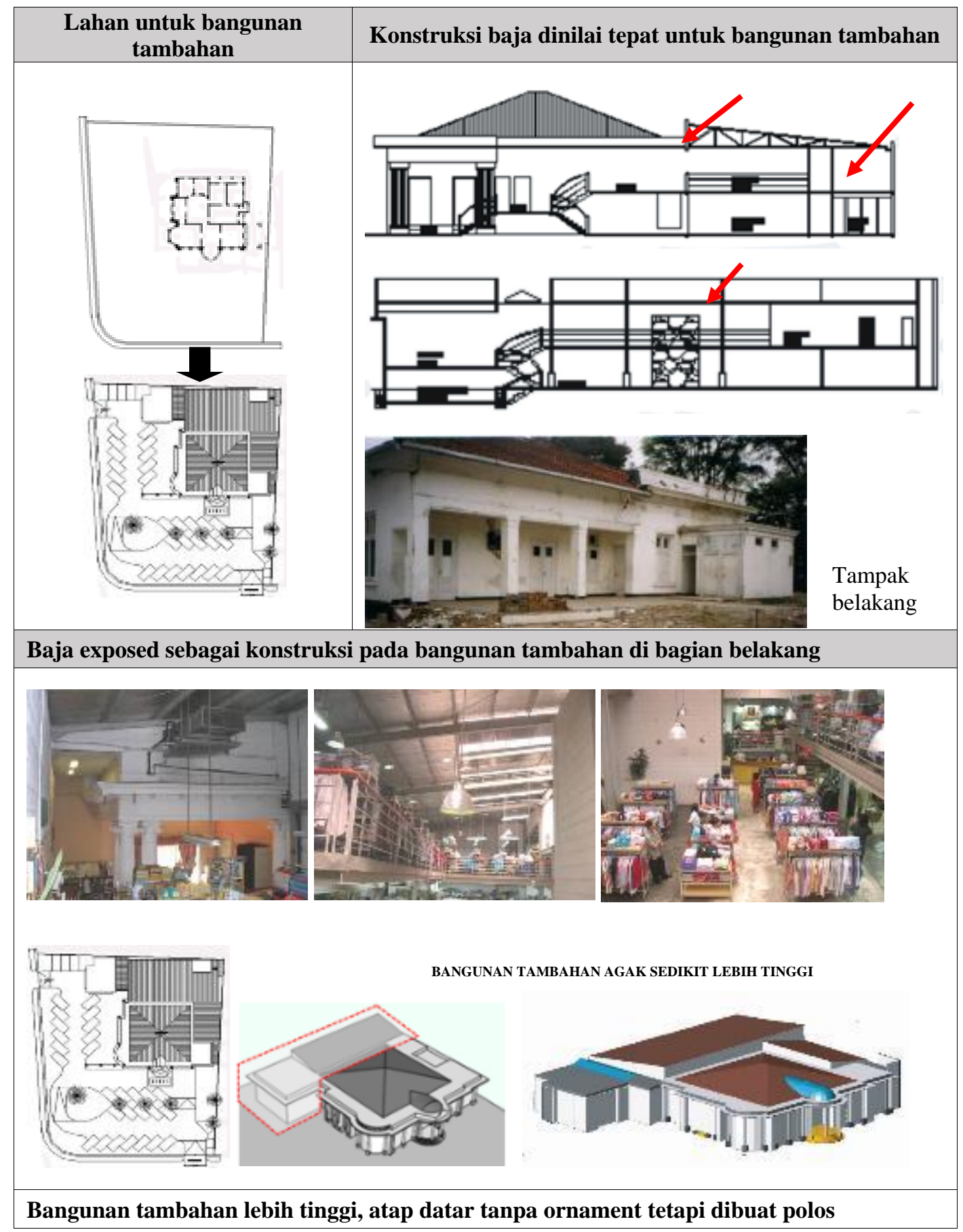

\section{Gambar 7: Bangunan tambahan di bagian belakang}

\subsection{Potensi Bangunan Kolonial}

Bangunan ini didirikan pada decade awal abad 19. Pada masa itu tipe rumah tinggal orang Belanda di seluruh Hindia Belanda disebut landhuis dengan ciri denah simetris, satu lantai dengan atap perisai. Karakteristik rumah terbuka dengan pilar dan mempunyai serambi di depan dan belakang. Selain itu di dalam rumah terdapat serambi tengah yang menuju ke ruang tidur dan kamar-kamar lainnya. Pilar menjulang tinggi dengan gaya Yunani dan terdapat gevel dan mahkota di atas serambi depan dan belakang. Serambi belakang berfungsi sebagai ruang makan dan terhubung dengan area servis di belakangnya [17]. 
Ciri dan karakter tersebut terdapat pada bangunan Heritage the Factory Outlet (gambar 3) dan menjadi potensi sebagai daya tarik para pembeli. Heritage merupakan pelopor alih fungsi bangunan di sepanjang jalan Riau sehingga saat factory outlet mendominasi bangunan di sepanjang jalan Riau [18].

Bentuk adaptasi bangunan kolonial terhadap iklim tropis tercermin pada bukaan daun pintu dan jendela yang lebar, plafond yang tinggi dan atap bangunan dengan sudut curam. Hal tersebut dimaksudkan untuk memperoleh sinar matahari yang maksimal sehingga rumah menjadi hangat dan terang sepanjang siang hari. Selain itu dengan bukaan tersebut memungkinkan terjadinya cross ventilation untuk mendapatkan kenyamanan termal di dalam bangunan. Saat ini potensi tersebut digunakan dengan baik, dengan penataan furniture, rak-rak pakaian untuk menaruh pakaian dan asesoris lainnya. (gambar 8)

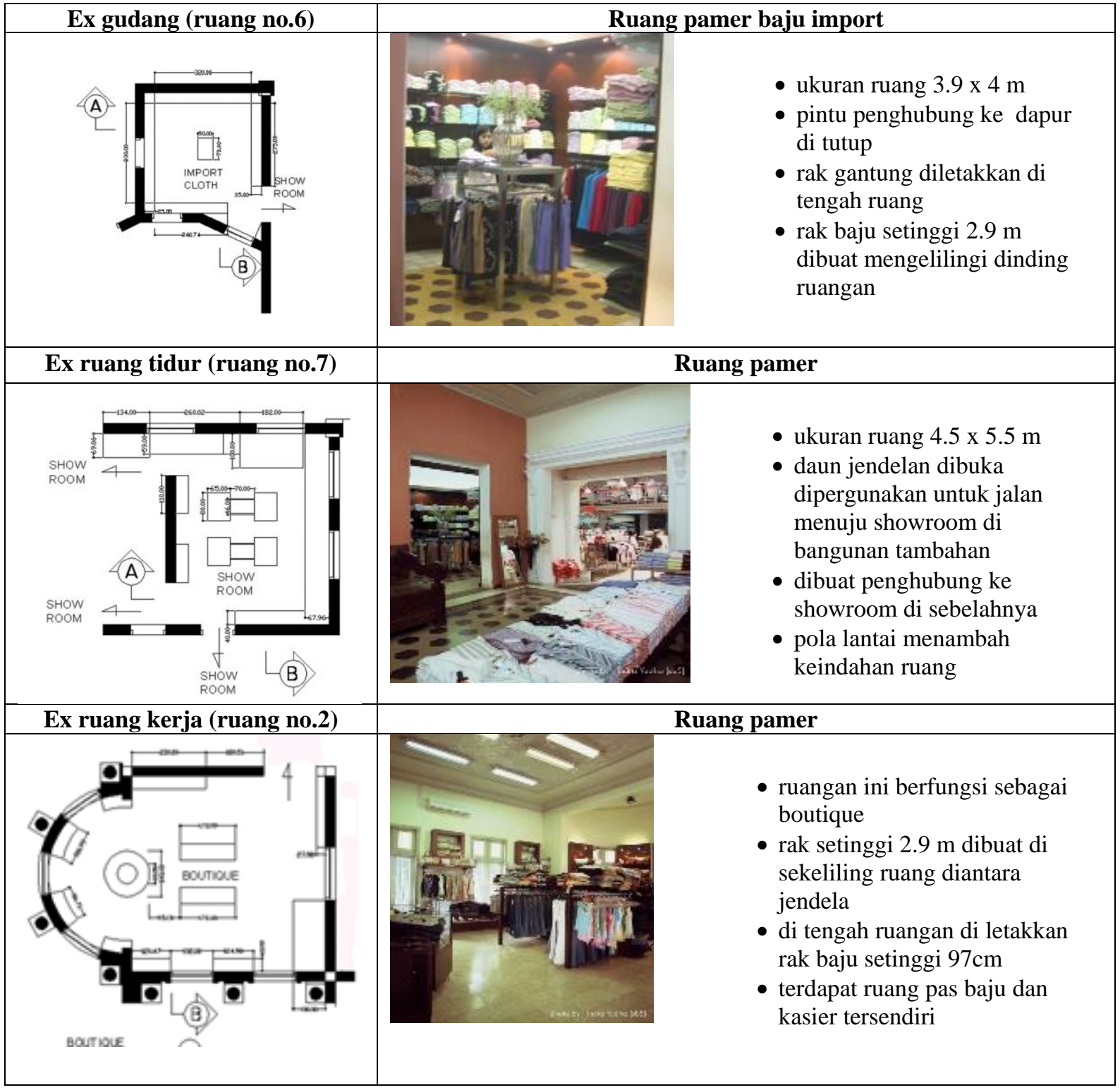

Gambar 8: Pemanfaatan ruang dalam menjadi showroom 


\section{KESIMPULAN}

Renovasi yang telah dilakukan pada bangunan 'Heritage' mengganti sebagian interior bangunan agar dapat beradaptasi terhadap fungsi barunya sebagai factory outlet. Adaptive reuse merupakan salah satu metoda untuk melestarikan bangunan dengan beradaptasi terhadap fungsi baru dengan tetap mempertahankan bentuk aslinya. Renovasi dan adaptive reuse yang dilakukan pada bangunan 'Heritage' diharapkan dapat menghidupkan sebuah kawasan bersejarah, yaitu kawasan eks perumahan militer di jl Riau atau R.E Martadinata Bandung.

Hasil studi memperlihatkan bahwa setelah direnovasi dan dialih fungsikan, bangunan tua masih terlihat cantik, mempunyai karakter spesifik yaitu karakter yang tidak dimiliki oleh bangunan baru. Kesuksesan alih fungsi bangunan 'Heritage' diikuti oleh bangunan-bangunan lainnya yang menjadikan jalan Riau menjadi tujuan wisatawan datang ke kota Bandung dan kawasan ini menjadi sebuah kawasan komersial yang unik dengan nuansa bangunan-bangunan bergaya kolonial sebagai daya tariknya.

Keberhasilan alih fungsi bangunan 'Heritage' kemudian diikuti oleh bangunan-bangunan lain di sepanjang jalan R.E Martadinata yang sebagian besar adalah bangunan milik Pemerintah, dalam hal ini Kodam Siliwangi. Bangunan-bangunan tersebut telah ditetapkan pula sebagai bangunan cagar budaya sehingga alih fungsi harus mengikuti aturan yang berlaku, yaitu tidak boleh merubah façade dan bentuk sehingga secara arsitektural gaya bangunan kolonial menjadi daya tarik utama.

Dampak negatif dari perubahan fungsi kawasan menjadi komersial adalah munculnya pedagang kaki lima yang umumnya memakai jalur hijau sebagai tempat berjualan. Selain itu kurangnya sarana parkir jalur hijau juga menjadi salah satu alternatif tempat parkir, kondisi ini merusak kawasan cagar budaya yang semula tertata dengan baik sebagai kawasan kolonial.

Selain itu penerapan billboard juga merusak kawasan apabila ditempatkan tidak sesuai aturan. Diharapkan aplikasi dari aturan konservasi untuk penerapan billboard dapat diterapkan dengan aturan yang ketat sehingga penerapan billboard tidak mengurangi keindahan wajah bangunan konservasi. Hal yang sama juga harus diterapkan pada penempatan billboard, terutama pada persimpangan jalan yang dianggap strategis dengan nilai jual tempat untuk billboard lebih tinggi dari tempat lain.

Jalan R.E Martadinata sebagai bagian dari kawasaan militer yang merupakan salah satu kawasan cagar budaya di Bandung saat ini telah berubah menjadi kawasan komersial tetapi wajah kawasan sebagai kawasan eks kolonial masih tercermin pada façade dan bentuk bangunannya. Jl R.E Martadinata sebagai kawasan yang masih memiliki warisan bangunan kolonial selayaknya tidak hanya bangunannya saja yang dilestarikan tetapi juga tata letak dan kondisi lingkungannya sehingga keharmonisan kawasan dapat terjaga dengan baik.

\section{DAFTAR PUSTAKA}

[1] Voskuil, E., (1996).’Bandoeng, Beeld van een stad”, Purmerend: Asia Major.

[2] Kunto, H., (1984). "Wajah Bandoeng Tempo Doeloe", I. Bandung: PT Granesia.

[3] Purnomo, E., Hery, Waani, Judi, O., Wuisang, Cynthia, (2017). "Gaya \& Karakter Visual Arsitektur Kolonial Belanda Di Kawasan Benteng Oranje Ternate", Media Matrasain, eJournal Unsrat, vol. 14, no. 1, pp. 23-33

[4] Soewarno, N., (2004). “Adaptive Reuse 'HERITAGE' the Factory Outlet”, Lund.

[5] Brolin, B.C., (1980). "Architecture In Context fitting new building with old", New York.

[6] Anthony, A., (1992). "Poetics of Architecture: Theory of Design", New York: John Wiley \& Sons.

[7] Ananditya, A., Khrisma, Suastika, Made, Sumadyo, (2017). "Implementasi Arsitektur Berkelanjutan pada Strategi Perancangan Rusunawa di Surakarta”, J. Arsitektura, vol. 15, no.2. 
[8] Mitchel, J., (2002). "Adaptive reuse”, Massachusetts : Institute of Technology Cambridge, Massachusetts.

[9] Brebbia, L., Telles, C.A., Wrobel, J.C.F., (1984). "Boundary Element Techniques,Theory and Applications in Engineering", Berlin: Springer-Verlag.

[10] Sumalyo, Y., (1993). "Arsitektur Kolonial Belanda di Indonesia”, First Edit, Yogjakarta, Gajah Mada University, Press

[11] Hadinoto, (1996). "Perkembangan Kota dan Arsitektur Kolonial Belanda di Surabaya 18701940", Yogjakarta: ANDI, 1996

[12] Hartono, D., (2001) "Pesona Arsitektur Eklektik, Di luar Teknik di dalam Klasik Modern", Majalah Griya Asri no.210/014-Februari 2001(majalah Arsitektur-Interior-Taman dan lingkungan), Bandung, Februari.

[13] Tutuko, P., (2003). "CIRI KHAS ARSITEKTUR RUMAH BELANDA (Studi Kasus Rumah Tinggal Di Pasuruan)", Mintakat, J. Arsit., vol. 4, no. 1.

[14] Handayani T.W., (2017). "PERALIHAN FUNGSI BANGUNAN DI KORIDOR JALAN L.L.R.E MARTADINATA KOTA BANDUNG", Geo Planart, vol. Vol.1, no. No.1, pp. 45-54.

[15] Kurniawan C., Agus, Rumawan, Salain, Trimarianto, (2015). "KONSERVASI FASADE BANGUNAN KOLONIAL DI JALUR BELANDA, KOTA SINGARAJA, BALI", Ruang, $J$. Lingkung. Binaan, vol. 2, no. 2, pp. 149-168.

[16] Sukarno, N., Gayatri, Pipit, Antariksa, Antariksa, Suryasari, (2014). "KARAKTER VISUAL FASADE BANGUNAN KOLONIAL BELANDA RUMAH DINAS BAKORWIL KOTA MADIUN," J. Arsit. Nalars, vol. 13, no. 2, pp. 99-112.

[17] Hadinoto, (2010). "Arsitektur dan Kota-kota di Jawa pada masa Kolonial”, Yogjakarta: Graha Ilmu

[18] Soewarno, N., Duhita, D., (2019). "The Transformation of Heritage Buildings as Tourist Attraction : Adaptive Re-use of Colonial Buildings at a Bandung Conservation Area", vol. 156, no. Senvar 2018, pp. 131-140. 